\title{
VIBRIO METSCHNIKOVII AMONG DIARRHEAL PATIENTS DURING CHOLERA EPIDEMIC IN RECIFE BRAZIL
}

\author{
Vera MAGALHÃES (1), Adeíza BRANCO (2), Roberto deANDRADE LIMA (3) \& Marcelo MAGALHÃES (1)
}

\begin{abstract}
SUMMARY
Although known since the last century, Vibrio metschnikovii was only appropriately described and recognized as a new species within the genus Vibrio in 1978. Rarely is the organism linked to human disease. Only once has $V$. metschnikovii been incriminated as responsible for human diarrhea, and affecting an old woman who suffered from diabetes and had a hepatoma. During the first two years of the present cholera epidemic, which reached Recife in March, 1992, we screened for vibrio nearly 4000 diarrheal fecal specimens submitted to a private clinical laboratory for detection of enteropathogenic microorganisms. Now, we report six cases of diarrhea associated with $V$. metschnikovii affecting individuals not suffering of any apparent underlying systemic illness.
\end{abstract}

KEYWORDS: Vibrio metschnikovii; Diarrhea; Vibrio; Cholera.

\section{INTRODUCTION}

Vibrio metschnikovii, an oxidase-negative and nitrate-negative species, described in 1888 , redefined in $1978^{5}$, and extensively characterized in 1988 by FARMER et al. ${ }^{2}$, is rarely isolated in human infections. Most nonhuman strains of this species were isolated from river water, oysters, lobsters and sewage ?. Thus, $V$. metschnikovii is a vibrio species often isolated from the environment but rarely isolated from human clinical species. There are only four reports of human disease related or caused by $V$. metschnikovii and all have occurred in old or immunocompromised patients ${ }^{3.4}$. In most of these human cases, $V$. metschnikovii caused bacteremia and was recuperated from blood cultures ${ }^{3,4}$. To our knowledge, only once has $V$. metschnikovii been incriminated as responsible for human diarrhea; even so, the patient was an old person with diabetes and hepatoma ${ }^{8}$. It is rarely isolated from human feces and is still a doubtful enteropathogen. Now, we report six cases of diarrhea associated with $V$. metschnikovii affecting individuals not suffering of any apparent systemic illness, during the cholera epidemic in Recife.

\section{MATERIAL AND METHODS}

During the first two years of the present cholera epidemic, which reached Recife on March, 1992, we screened for Vibrio all diarrheal fecal specimens submitted to a private clinical laboratory for detection of enteropathogenic microorganisms. To avoid biasing due to seasonality, we only considered the specimens received between March and December 1992 and the specimens received on equal period of 1993.

For recovering Vibrio, fecal samples were enriched in alkaline peptone water $(\mathrm{pH} 8.5)$ supplemented with $2 \% \mathrm{NaCl}$ and subcultured to thiosulfate-citratebile salts-sucrose agar (TCBS; Difco Laboratories, De-

(1) Departamento de Medicina Tropical da Universidade Federal de Pernambuco (UFPE), Laboratório de Imunopatologia Keizo Asami (Lika-UFPE).

(2) Mestranda do Mestrado em Medicina Tropical da UFPE.

(3) Departamento de Medicina Clínica da UFPE.

Correspondence to: Vera Magalhães - Estrada do Arraial 2823/1701, 52051-380, Recife, PE, Brasil. Fone/Fax: (081) 4416169 
troit, Mich). Colonies suspected of Vibrio were purified on sheep blood agar and biochemically characterized by using standard methods '.

\section{RESULTS AND DISCUSSION}

Nearly 4000 diarrheal fecal specimens were submitted to a private laboratory during the first two years of the present cholera epidemic. Between March and December, 1992, 2200 fecal samples were examined, and 1700 specimens were examined on equal period of 1993.

Interestingly, among 73 strains of non-cholera vibrios identified, $6(8.2 \%)$ were classified as $V$. metschnikovii (table 1). Of these, five strains were recovered from diarrheal patients as the sole enteropathogen, and the last one jointly with Salmonella sp. All patients from whom $V$. metschnikovii was isolated were in good health until the development of the enteritis. Of the six patients, five were adults and three denied exposure to seafood. Clinically, the diarrhea was mild, brief, selflimited, and characterized by cramps and watery stools. No fecal leukocytes were seen on Gram stained smears.

The six $V$. metschnikovii strains showed a highly uniform biochemical testing profile. Positive tests for all the strains included growth on TCBS, growth at $40^{\circ} \mathrm{C}$, requirement for $\mathrm{NaCl}$, beta-hemolysis on sheep blood agar, sensitivity to $0 / 129$ (150 $\mu \mathrm{g}$ per disk), hydrolysis of Tween 80 and esculin, arginine dihydrolase, and fermentation of sucrose, mannitol, inositol, and glycerol. Negative tests included oxidase, nitrate reduction, indole, O-nitrophenyl-B-D-galactopyranoside, growth in $8 \% \mathrm{NaCl}$, ornithine decarboxylase, gas production from glucose, and fermentation of arabinose, lactose, salicin, and sorbitol. Results of other tests, lysine decarboxylase and VogesProskauer, were strain dependent. Whereas the organism is easily separated

TABLE 1

Non-cholera Vibrio isolated during two years of the cholera epidemic in Recife, Brazil

\begin{tabular}{lcr}
\hline Species & 1992 & 1993 \\
\hline V. cholerae non-01 & 9 & 4 \\
V. alginolyticus & 1 & 1 \\
V. fuvialis & 3 & 3 \\
V. furnissii & 5 & 15 \\
V. metschnikovii & 5 & 1 \\
V. parahaemolyticus & 5 & 21 \\
Vibrio spp. & 1 & 1 \\
\hline
\end{tabular}

from other vibrios because it is oxidase-negative, such peculiarity impeds its rapid recognition as a member of the genus Vibrio in clinical laboratories. Perhaps, we detected somewhat many strains of $V$. metschnikovii because all yellow colonies seen on TCBS plates were submitted to biochemical identification simultaneously with oxidase testing, that is, oxidase-positivity was not a prerequisite for considering the strains as a vibrio.

The clinical significance of the present findings is not clear. We routinely use TCBS in our laboratory since 1989 and until the cholera epidemic started in 1992, no strain of $V$. metschnikovii had been recognized. In fact, fear of cholera changed the behavior of people now studied, individuals belonging to good or middle socioeconomic levels ? The epidemic stimulated such people to submit for culturing many stool samples, yet from mild cases of diarrhea. People also altered their diet, abstaining from seafood and from visiting restaurants. Despite this, $V$. cholerae non-01 and $V$. metschnikovii were more frequently found on this year than on 1993, showing that seafood is not an usual source for human infections with these species. In contrast, on the second year of the epidemic, when the anxiety about cholera vanished and people returned to old alimentary habits, recovering of other vibrios increased steadily $(\mathrm{p}=0.002)$. This was mainly due to a rising in the frequency of $V$. parahaemolyticus and $V$. furnissii, the most common vibrios identified in Recife before the epidemic (Table 1). Strains of $V$. cholerae 01 also were more frequently found on the second year of the outbreak, an apparent paradoxy, since it would be expected a larger number of $V$. cholerae 01 on the first months of epidemic ${ }^{7}$. Thus anxiety about cholera influences the isolation rate and the kind of vibrio species from people of good standard of life.

Albeit $V$. metschnikovii has at least a potential factor of virulence, a powerful cytolysin with enterotoxic activity ${ }^{8}$, further studies are necessary to decide whether present results are a laboratory curiosity, incidental to the cholera epidemic in Brazilian northeast, or whether they have some clinical relevance.

\section{RESUMO}

\section{Vibrio metschnikovii entre pacientes diarréicos durante epidemia de cólera no Recife, Brasil.}

Embora reconhecido desde o século passado, o Vibrio metschnikovii só foi descrito e classificado de 
MAGALHÃES, V.; BRANCO, A.; ANDRADE LIMA R. de \& MAGALHÃES, M. - Vibrio metschnikovii among diarrheal patients during cholera epidemic in Recife, Brazil. Rev. Inst. Med. trop. S. Paulo, 38(1): 1-3, 1996.

forma apropriada dentro do gênero Vibrio em 1978. Raramente, essa bactéria tem sido relacionada com doença humana, acometendo habitualmente, pacientes imunodeprimidos. Há apenas um relato de gastroenterite a $V$. metschnikovii. Durante a recente epidemia de cólera, que acometeu o Recife em março de 1992, todos os espécimes fecais diarréicos submetidos a um laboratório particular de patologia clínica para diagnóstico microbiológico, foram também cultivados em meio tiosulfato, citrato, sais biliares e sacarose (TCBS). Analizou-se um total de 4000 amostras fecais durante os dois anos que se seguiram a chegada da cólera ao Recife. No presente, reportamos seis casos de diarréia a $V$. metschnikovii ocorridos nesse período.

\section{REFERENCES}

1. BAUMANN, P.: FURNISS, A. L. \& LEE, J. V. - Genus I. Vibrio Pacine 1854. In: KRIEG, N. R. \& HOLT, J. G., ed. Bergey's manual of systematic bacteriology. Baltimore, Williams \& Wilkins, 1984. p. 518-538.

2. FARMER III, J. J.; HICKMAN-BRENNER, F. W ; FANNING, G. R.; GORDON, C. M. \& BRENNER, D. J. - Characterization of Vibrio metschnikovii and Vibrio gazogenes by DNA-DNA hybridization and phenotype. J. clin. Microbiol., 26: 1993-2000, 1988.

3. HANSEN, W.; FRENEY, J.; BENYAGOUB, H. et al. - Severe human infections caused by Vibrio metschnikovii. J. clin. Microbiol., 31: 2529-2530, 1993.

4. JEAN-JACQUES, W.; RAJASHEKARAIAH, K. R.; FARMER III, J. J. et al. - Vibrio metschnikovii bacteremia in a patient with cholecystitis. J. clin. Microbiol., 14: 711-712, 1981.

5. LEE. J. V.; DONOVAN, T. J. \& FURNISS, A. L. - Characterization, taxonomy, and emended description of Vibrio metschnikovii. Int. J. system. Bact., 28: 99-111, 1978.

6. MAGALHĀES, V; MAGALHĀES, M:; ANDRADE-LIMA, R; TATENO, S. \& MAGALHÃES, E. - Vibriōes não coléricos na rotina enterobacteriológica. Rev. Inst. Med. trop. S. Paulo, 34: 131-135, 1992.

7. MAGALHÃES, V.: MAGALHÃES, M. \& MARQUES, L. R. M. Vibrios among patients of good socioeconomic conditions during the cholera epidemic in Recife, Brazil. Rev. Inst. Med. trop. S. Paulo, 35: 345-346, 1993.

8. MIYAKE, M.; HONDA, T. \& MIWATANI, T. - Purification and characterization of Vibrio metschnikovii cytolysin. J. clin. Microbiol., 56: 954-960, 1988.

Recebido para publicação em 22/11/1995. Aceito para publicação em 08/01/1996. 